\title{
molecules
}

ISSN 1420-3049

www.mdpi.com/journal/molecules

Article

\section{Assessing Chemical Constituents of Mimosa caesalpiniifolia Stem Bark: Possible Bioactive Components Accountable for the Cytotoxic Effect of M. caesalpiniifolia on Human Tumour Cell Lines}

\section{Nayana Bruna Nery Monção ${ }^{1}$, Bruno Quirino Araújo ${ }^{1}$, Jurandy do Nascimento Silva ${ }^{2}$, Daisy Jereissati Barbosa Lima ${ }^{3}$, Paulo Michel Pinheiro Ferreira ${ }^{2,4}$,} Flavia Pereira da Silva Airoldi ${ }^{5}$, Cláudia Pessoa ${ }^{3,6}$ and Antonia Maria das Graças Lopes Citó ${ }^{1, *}$

1 Department of Chemistry, Federal University of Piauí, Teresina 64049-550, PI, Brazil; E-Mails: nayaninhanery@hotmail.com (N.B.N.M.); bquirinoa@hotmail.com (B.Q.A.)

2 Postgraduate Program in Pharmaceutical Sciences, Federal University of Piauí, Teresina 64049-550, PI, Brazil; E-Mails: jurandy@ifpi.edu.br(J.N.S.); pmifepe@yahoo.com.br (P.M.P.F.)

3 Department of Physiology and Pharmacology, Federal University of Ceará, Fortaleza 60430-270, CE, Brazil; E-Mails: daisylima@gmail.com (D.J.B.L.); cpessoa@ufc.br (C.P.)

4 Department of Biophysics and Physiology, Federal University of Piauí, Teresina 64049-550, PI, Brazil

5 Laboratory of Organic Geochemistry, University of Campinas, São Paulo 13083-970, SP, Brazil; E-Mail: flavia_aguayo@yahoo.com.br

6 Oswald Cruz Foundation, Fortaleza 60180-900, CE, Brazil

* Author to whom correspondence should be addressed; E-Mail: gracacito@gmail.com; Tel.: +55-86-3237-1584.

Academic Editor: Derek J. McPhee

Received: 21 November 2014 / Accepted: 26 January 2015 / Published: 5 March 2015

\begin{abstract}
Mimosa caesalpiniifolia is a native plant of the Brazilian northeast, and few studies have investigated its chemical composition and biological significance. This work describes the identification of the first chemical constituents in the ethanolic extract and fractions of M. caesalpiniifolia stem bark based on NMR, GC-qMS and HRMS analyses, as well as an assessment of their cytotoxic activity. GC-qMS analysis showed fatty acid derivatives, triterpenes and steroid substances and confirmed the identity of the chemical compounds isolated from the hexane fraction. Metabolite biodiversity in M. caesalpiniifolia stem bark revealed the differentiated accumulation of pentacyclic triterpenic acids, with a high content of betulinic acid and minor amounts of 3-oxo and $3 \beta$-acetoxy derivatives.
\end{abstract}


Bioactive analysis based on total phenolic and flavonoid content showed a high amount of these compounds in the ethanolic extract, and ESI-(-)-LTQ-Orbitrap-MS identified caffeoyl hexose at high intensity, as well as the presence of phenolic acids and flavonoids. Furthermore, the evaluation of the ethanolic extract and fractions, including betulinic acid, against colon (HCT-116), ovarian (OVCAR-8) and glioblastoma (SF-295) tumour cell lines showed that the crude extract, hexane and dichloromethane fractions possessed moderate to high inhibitory activity, which may be related to the abundance of betulinic acid. The phytochemical and biological study of $M$. caesalpiniifolia stem bark thus revealed a new alternative source of antitumour compounds, possibly made effective by the presence of betulinic acid and by chemical co-synergism with other compounds.

Keywords: Mimosa caesalpiniifolia; phenolic compounds; cytotoxicity; betulinic acid

\section{Introduction}

Mimosa L. (Fabaceae) is the second largest genus of the Mimosoideae subfamily and comprises approximately 530 species, distributed mainly in South and Central America [1-3]. Despite the great biodiversity of the genus Mimosa, phytochemical and pharmacological studies are restricted to about twenty representatives, of which Mimosa pudica and Mimosa tenuiflora are the most commonly investigated species.

Mimosa species are rich in polyphenol compounds such as flavonoids (e.g., flavones, flavonols), lignans and other phytochemicals, including alkaloids, terpenoids, steroids and saponins [4-8]. In pharmacological investigations, Mimosa species are mainly characterised by their antioxidant potential [4,9] and antimicrobial activity [10,11]. However, studies investigating acetylcholinesterase [12], antiulcerogenic [13], antidiabetic [14], anti-inflammatory [15], antifungal [16], antinociceptive [17] and cytotoxic effects [18] of Mimosa species have also been described.

Mimosa caesalpiniifolia Benth. (syn. Mimosa caesalpiniaefolia) is a native plant to northeastern Brazil, popularly known as "unha-de-gato", "sabiá", "angiquinho-sabiá" and "sansão do campo" [19,20]. Due to their therapeutic effects, the stem bark and flowers have been used in traditional medicine for the treatment of bronchitis, skin infections and injuries [21] and for inflammation and hypertension [22], respectively. Therefore, detailed phytochemical studies are necessary to identify the active compound(s) for phytotherapeutic product development and to possibly aid in the search for new drugs. Taking into account previous chemical and pharmacological studies of M. caesalpiniifolia [23,24] and screenings for the antiproliferative activity of Brazilian species, this work describes the first phytochemical study of $M$. caesalpiniifolia stem bark. Non-polar compounds and acid derivatives of hexane and dichloromethane fractions were analysed by GC-qMS, and polar compounds from ethanolic extract were identified by HRMS and $\mathrm{MS}^{\mathrm{n}}$ experiments. Additionally, ethanolic extract, fractions and isolated compounds were evaluated for cytotoxic activity against the HCT-116, OVCAR-8 and SF-295 human tumour cell lines. 


\section{Results and Discussion}

The extraction of M. caesalpiniifolia stem bark yielded a crude ethanolic extract with $4.2 \%(\mathrm{w} / \mathrm{w})$ extractable matter. Partitioning of the EtOH extract of $M$. caesalpiniifolia with different solvents yielded fractions at extraction efficiencies ranging from $7.4 \%$ to $37.7 \%$. The aqueous fraction had the highest extraction efficiency $(37.7 \%, \mathrm{w} / \mathrm{w})$, whereas the $n$-hexane fraction presented the lowest extraction efficiency $(7.4 \%, \mathrm{w} / \mathrm{w})$. The efficiency of fractionation for different fractions in descending order was as follows: aqueous $>$ dichloromethane $>$ ethyl acetate $>$ hexane.

\subsection{Phytochemical Analysis}

The chromatographic separation of the hexane fraction of ethanolic stem bark extract from Mimosa caesalpiniifolia led to the isolation and characterisation of campestenone (1), $\beta$-amyrin (2), stigmasta-4,22-dien-3-one (3), lupeol (4), sitostenone (5), 3 $\beta$-acetoxy-olean-18-en-28-oic acid (6), campesterol (7), stigmasterol (8), sitosterol (9) and betulinic acid (10) (Figure 1). The structures 1-10 were confirmed by comparison of TLC, GC-qMS, HRAPCIMS, ${ }^{1} \mathrm{H}-,{ }^{13} \mathrm{C}-\mathrm{NMR}$ and DEPT analyses with data from the literature [25-27].

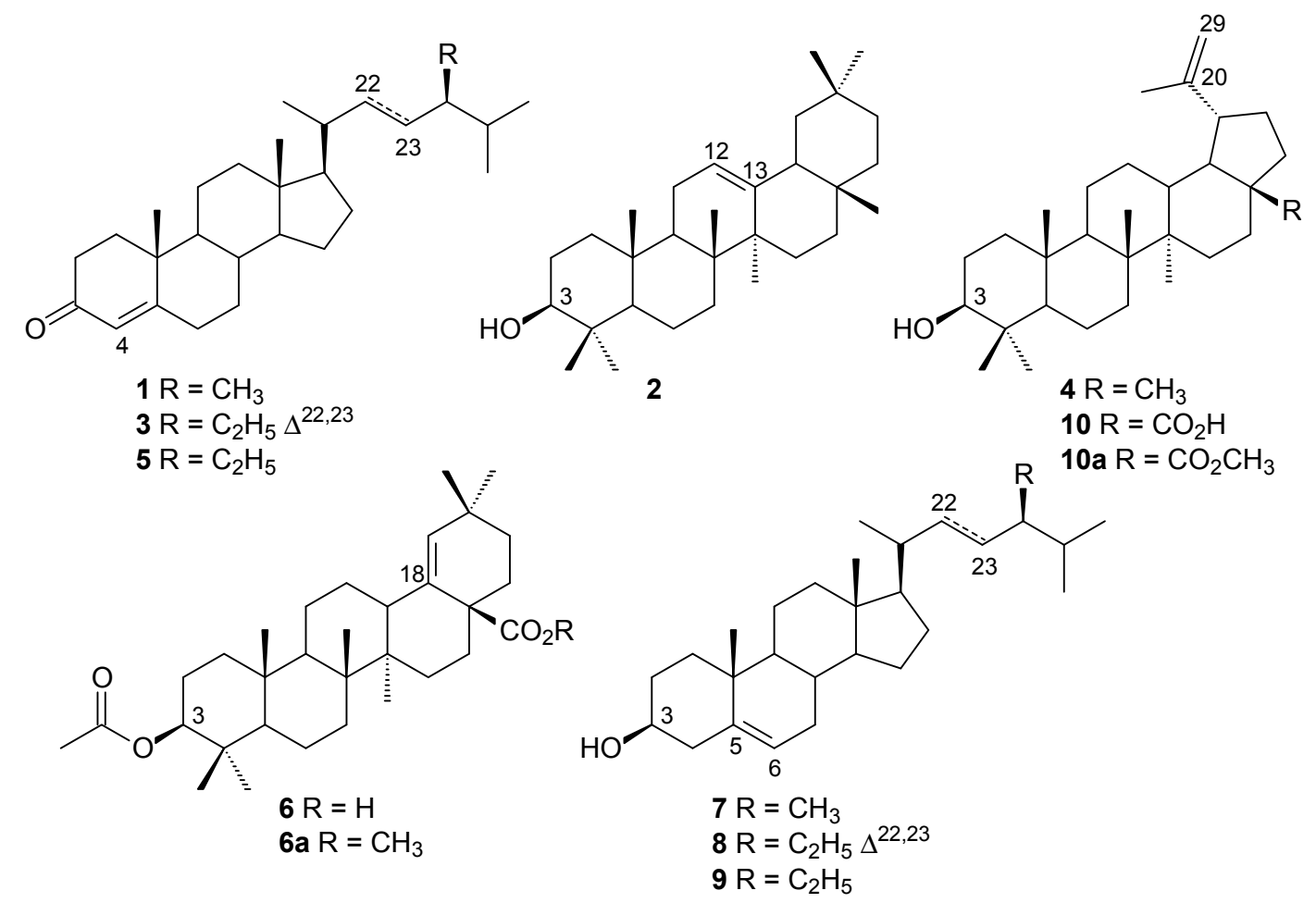

Figure 1. Chemical constituents isolated from the hexane fraction of the ethanolic stem bark extract of Mimosa caesalpiniifolia.

The ${ }^{1} \mathrm{H}$ - and ${ }^{13} \mathrm{C}-\mathrm{NMR}$ spectra of subfraction F2 showed signals at $\delta_{\mathrm{H}} 3.19(d d, J=5.1$ and $11.2 \mathrm{~Hz}$, $\mathrm{H}-3)$ and $\delta_{\mathrm{C}} 79.2$ characteristic of $3 \beta-\mathrm{OH}$ triterpenoids. The signals at $\delta_{\mathrm{H}} 4.56$ and $4.68(\mathrm{H} 29 \alpha$ and $\mathrm{H} 29 \beta)$ and $\delta_{\mathrm{C}} 109.5$ (C-29) and 151.1 (C-20) were assigned to olefinic carbons in the lup-20(29)-ene skeleton. GC-qMS analysis showed a peak of high relative abundance $(60.9 \%)$ with a molecular ion at $\mathrm{m} / \mathrm{z} 426\left[\mathrm{M}^{+*}\right]$, which suggested lupeol (4). Furthermore, the signal at $\delta_{\mathrm{H}} 5.73$, attributed to olefinic 
hydrogen H-4 in a steroidal nucleus with a carbonyl group at C-3, and the signal at $\delta_{\mathrm{C}} 199.9$ (C-3) suggested a 3-ketosteroid structure. The presence of stigmasta-4,22-dien-3-one (3) was suggested by signals at $\delta_{\mathrm{H}} 5.02$ and $5.15(d d, J=8.6$ and $15.2 \mathrm{~Hz})$, assigned to methine protons $\mathrm{H}-22$ and $\mathrm{H}-23$; signals at $\delta_{\mathrm{C}} 129.6$ (C-22) and 138.2 (C-23) characteristic of stenone-like compounds; and the results of GC-qMS analysis, which showed a peak with $11.4 \%$ relative abundance at $m / z 410\left(\left[\mathrm{M}^{+*}\right]\right.$, EIMS data) compatible with formula $\mathrm{C}_{29} \mathrm{H}_{46} \mathrm{O}$.

Other peaks in the total ion chromatogram (TIC) were identified as campestenone $+\beta$-amyrin $(\mathbf{1}+\mathbf{2}, \mathbf{8 . 7 \%})$, sitostenone $(\mathbf{5}, 7.5 \%)$ and 3 $\beta$-O-acetyl-olean-18-en-28-oic acid methyl ester $(\mathbf{6 a}, 11.5 \%)$ (Figure S1, Supplementary Materials). The triterpene $\beta$-amyrin was detected in the subfraction F2 in coelution with campestenone, based on the extracted ion chromatogram (EIC) results at $\mathrm{m} / z 124$ (3-ketosteroid) and $m / z 218$ (base peak, 3 $\beta$-hydroxy-olean-12-ene skeleton) and GC-qMS analysis of the subfraction F2-1. This subfraction showed a pentacyclic triterpene mixture of $\beta$-amyrin and lupeol $(2+4)$ with relative abundance at $3.0 \%$ and $97.0 \%$, respectively, based on retention time and mass spectral data (Figure S1, Supplementary Materials). The triterpenoid 3 $\beta$-acetoxy-olean-18-en-28-oic acid methyl ester (6a) was only detected in the GC-qMS analysis of methylated subfraction F2, i.e., the chemical compound $\mathbf{6 a}$ occurs in $M$. caesalpiniifolia stem bark as free triterpenic acid $\mathbf{6}$.

The steroid mixture $(\mathrm{F} 3,7+\mathbf{8}+\mathbf{9})$ showed a multiplet at $\delta_{\mathrm{H}} 3.52(\mathrm{H}-3)$ and $\delta_{\mathrm{H}} 5.34(d, 5.2 \mathrm{~Hz})$, assigned to H-6 for campesterol (7), stigmasterol (8) and sitosterol (9), and at $\delta_{\mathrm{H}} 5.01$ and $5.15(d d$, $J=8.6$ and $15.2 \mathrm{~Hz}$ ), assigned to methine protons $\mathrm{H}-22$ and $\mathrm{H}-23$ for stigmasterol $(\mathbf{8})$. The ${ }^{13} \mathrm{C}-\mathrm{NMR}$ spectra showed oxymethine carbon at $\delta_{\mathrm{C}} 71.9$ and $\delta_{\mathrm{C}} 140.9(\mathrm{C}-5)$ and $121.8(\mathrm{C}-6)$ for steroid $3 \beta-\mathrm{OH}$ with a $\Delta^{5}$ skeleton $(7+\mathbf{8}+\mathbf{9})$. The methine carbons at $\delta_{C} 129.4(\mathrm{C}-23)$ and $138.4(\mathrm{C}-22)$ confirmed a stigmasterol compound (8). The assignment of steroid side-chain signals in ${ }^{13} \mathrm{C}-\mathrm{NMR}$ analysis allowed the identification of campesterol (7) and sitosterol (9), based on signals at $\delta_{\mathrm{C}} 30.4,39.0,32.6,20.4$, 18.4 and 15.5; and $\delta_{\mathrm{C}} 26.2,46.0,29.3,20.0,19.2$ and 23.2, respectively, attributed to C-23, C-24, C-25, C-26, C-27 and C-28 in the steroids [27]. The steroid mixture (subfraction F3) showed a TIC in GC-qMS analysis (Figure S1, Supplementary Materials) with three peaks, corresponding to the following molecular ions: $m / z 400$ (7, 10.1\%), 412 (8, 72.1\%) and 414 (9, 17.8\%), respectively; stigmasterol (8) was identified as a major compound.

The ${ }^{1} \mathrm{H}$ - and ${ }^{13} \mathrm{C}-\mathrm{NMR}$ analysis of subfraction $\mathrm{F} 4$ showed signals similar to a $3 \beta$-hydroxy-lup20(29)-ene skeleton, except for the presence of a signal at $\delta_{\mathrm{C}} 181.4$, which indicated a carbonyl group in $\mathrm{C}-28$ and the absence of $\delta_{\mathrm{C}} 18.1\left(\mathrm{CH}_{3}\right)$. The total ion chromatogram showed one peak for the methylated sample (Figure S1, Supplementary Materials) and EIMS revealed an ion at $\mathrm{m} / z \quad 470\left[\mathrm{M}^{+\bullet}\right.$ ] in GC-qMS analysis and fragment ions at $\mathrm{m} / z 189$ (base peak, 100\%) and $\mathrm{m} / \mathrm{z} 207$ (37\%). This result suggests triterpenoid structures characteristic of a lupane skeleton, and the ion at $\mathrm{m} / z 262(27 \%)$ is indicative of a triterpenoid C-28 methyl ester derivatives. HRAPCIMS in negative mode showed a deprotonated ion at $m / z 455.3510[\mathrm{M}-\mathrm{H}]^{-}$(calculated for $\mathrm{C}_{30} \mathrm{H}_{47} \mathrm{O}_{3}, 455.3524$ ) and $469.3672[\mathrm{M}-\mathrm{H}]^{-}$ (calculated for $\mathrm{C}_{31} \mathrm{H}_{49} \mathrm{O}_{3}, 469.3681$ ), which confirmed the structures of betulinic acid (10) and methyl betulinate (10a, a synthetic derivative), respectively. 


\subsubsection{Non-Polar Compounds and Acid Derivatives of M. caesalpiniifolia by GC-qMS}

Analysis of the chemical composition of extracts, fractions and natural compounds by GC-qMS is a useful tool in phytochemical studies for the separation and identification of individual compounds from organic matrices, especially in bioactivity-guided studies [28]. To determine the phytoconstituents and fatty acids of M. caesalpiniifolia stem bark, the hexane and dichloromethane fractions were methylated using diazomethane solution. The GC-qMS profiles of the methylated hexane and dichloromethane fractions from the ethanolic extract of M. caesalpiniifolia are shown in Figure 2.

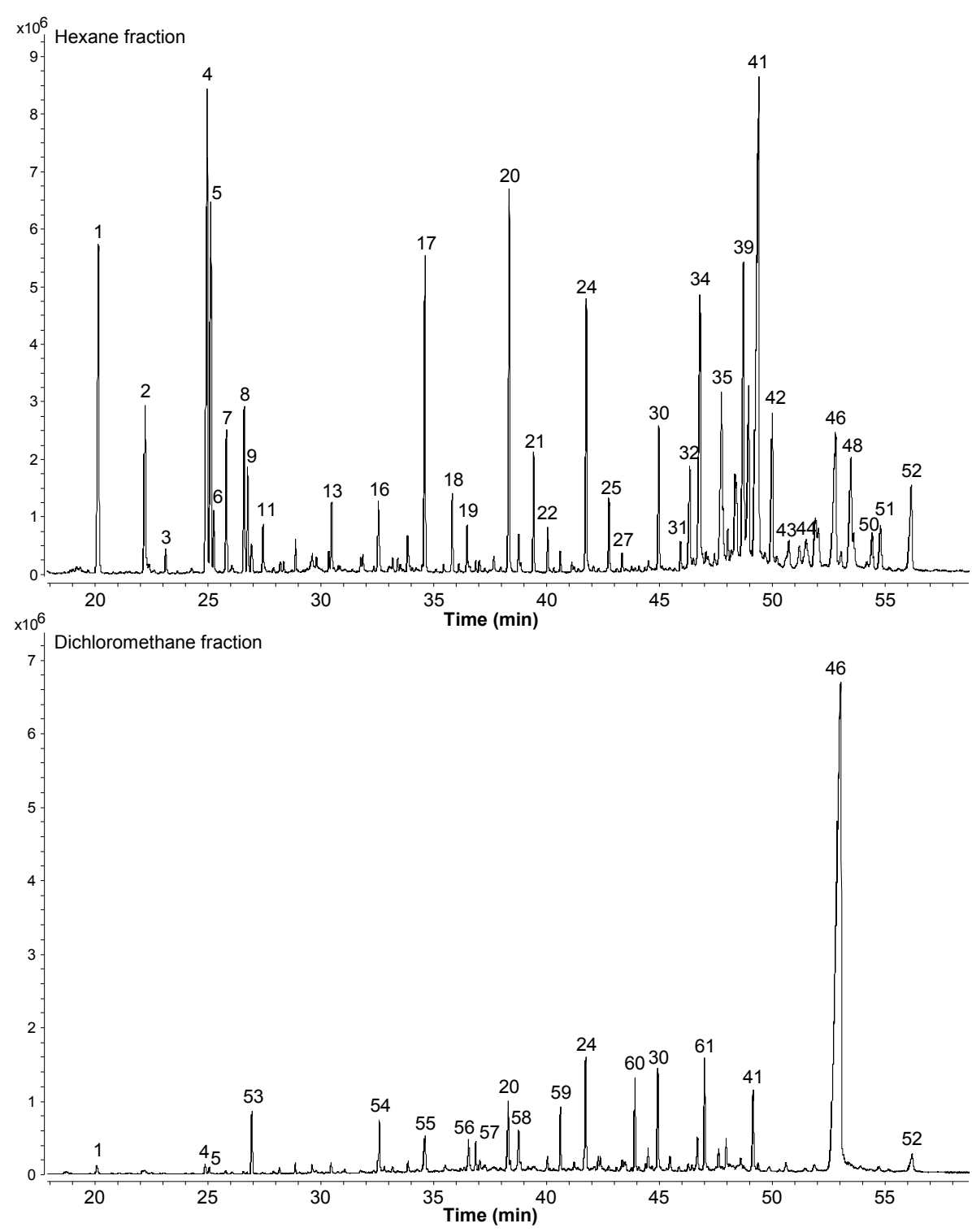

Figure 2. Total ion chromatogram (TIC) of hexane and dichloromethane fractions of Mimosa caesalpiniifolia in GC-qMS analysis.

The relative abundance (\%), molecular ion, formula and retention time of the compounds identified in the hexane and dichloromethane fractions of M. caesalpiniifolia by GC-qMS analysis are shown in Table 1. 
Table 1. Chemical compounds (\%) identified by GC-qMS analysis of hexane and dichloromethane fractions of ethanolic stem bark extract of Mimosa caesalpiniifolia.

\begin{tabular}{|c|c|c|c|c|c|c|}
\hline & Chemical Constituents & Molecular Formula & $\operatorname{EIMS}\left[\mathbf{M}^{+\bullet}\right]$ & Rt (min) & HEX $(\%)$ & DCM $(\%)$ \\
\hline 1 & Methyl hexadecanoate C16:0 & $\mathrm{C}_{17} \mathrm{H}_{34} \mathrm{O}_{2}$ & 270 & 20.16 & 6.05 & 0.33 \\
\hline 2 & Ethyl hexadecanoate C16:0 & $\mathrm{C}_{18} \mathrm{H}_{36} \mathrm{O}_{2}$ & 284 & 22.23 & 2.43 & \\
\hline 3 & Methyl heptadecanoate C17:0 & $\mathrm{C}_{18} \mathrm{H}_{36} \mathrm{O}_{2}$ & 284 & 23.14 & 0.34 & \\
\hline 4 & Methyl $(9 Z, 12 Z)$ octadeca-9,12-dienoate C18:2 & $\mathrm{C}_{19} \mathrm{H}_{34} \mathrm{O}_{2}$ & 294 & 24.98 & 8.05 & 0.32 \\
\hline 5 & Methyl (9Z)-octadec-9-enoate C18:1 & $\mathrm{C}_{19} \mathrm{H}_{36} \mathrm{O}_{2}$ & 296 & 25.15 & 5.13 & 0.13 \\
\hline 6 & Methyl (11Z)-octadec-11-enoate C18:1 & $\mathrm{C}_{19} \mathrm{H}_{36} \mathrm{O}_{2}$ & 296 & 25.27 & 0.62 & \\
\hline 7 & Methyl octadecanoate C18:0 & $\mathrm{C}_{19} \mathrm{H}_{38} \mathrm{O}_{2}$ & 298 & 25.84 & 1.73 & \\
\hline 8 & Ethyl (9Z,12Z)-octadeca-9,12-dienoate C18:2 & $\mathrm{C}_{20} \mathrm{H}_{36} \mathrm{O}_{2}$ & 308 & 26.63 & 2.04 & \\
\hline 9 & Ethyl (9Z)-octadec-9-enoate C18:1 & $\mathrm{C}_{20} \mathrm{H}_{38} \mathrm{O}_{2}$ & 310 & 26.78 & 1.21 & \\
\hline 10 & Ethyl(11Z)-octadec-11-enoate C18:1 & $\mathrm{C}_{20} \mathrm{H}_{38} \mathrm{O}_{2}$ & 310 & 26.94 & 0.44 & \\
\hline 53 & Unidentified & & & 26.97 & & 2.17 \\
\hline 11 & Ethyl octadecanoate C18:0 & $\mathrm{C}_{20} \mathrm{H}_{40} \mathrm{O}_{2}$ & 312 & 27.46 & 0.53 & \\
\hline 12 & Methyl (10Z,13Z)-nonadeca-10,13-dienoate C19:2 & $\mathrm{C}_{20} \mathrm{H}_{36} \mathrm{O}_{2}$ & 308 & 27.92 & 0.08 & \\
\hline 13 & Methyl nonadecanoate C19:0 & $\mathrm{C}_{20} \mathrm{H}_{40} \mathrm{O}_{2}$ & 312 & 28.23 & 0.17 & \\
\hline 14 & Methyl eicosanoate C20:0 & $\mathrm{C}_{21} \mathrm{H}_{42} \mathrm{O}_{2}$ & 326 & 30.49 & 0.75 & \\
\hline 15 & Ethyl eicosanoate C20:0 & $\mathrm{C}_{22} \mathrm{H}_{44} \mathrm{O}_{2}$ & 340 & 31.89 & 0.14 & \\
\hline 16 & Methyl heneicosanoate C21:0 & $\mathrm{C}_{22} \mathrm{H}_{44} \mathrm{O}_{2}$ & 340 & 32.56 & 1.14 & \\
\hline 54 & Unidentified & & & 32.62 & & 1.32 \\
\hline 17 & Methyl docosanoate C22:0 & $\mathrm{C}_{23} \mathrm{H}_{46} \mathrm{O}_{2}$ & 354 & 34.63 & 3.85 & \\
\hline 55 & Unidentified & & & 34.64 & & 1.76 \\
\hline 18 & Ethyl docosanoate C22:0 & $\mathrm{C}_{24} \mathrm{H}_{48} \mathrm{O}_{2}$ & 368 & 35.84 & 0.84 & \\
\hline 19 & Methyl tricosanoate C23:0 & $\mathrm{C}_{24} \mathrm{H}_{48} \mathrm{O}_{2}$ & 368 & 36.49 & 0.49 & \\
\hline
\end{tabular}


Table 1. Cont.

\begin{tabular}{|c|c|c|c|c|c|c|}
\hline & Chemical Constituents & Molecular Formula & EIMS $\left[\mathbf{M}^{+\bullet}\right]$ & Rt (min) & HEX (\%) & DCM (\%) \\
\hline 56 & Unidentified & & & 36.56 & & 0.79 \\
\hline 57 & Unidentified & & & 36.87 & & 0.76 \\
\hline 20 & Methyl tetracosanoate $\mathrm{C} 24: 0$ & $\mathrm{C}_{25} \mathrm{H}_{50} \mathrm{O}_{2}$ & 382 & 38.36 & 4.95 & 2.16 \\
\hline 58 & Unidentified & & & 38.78 & & 1.21 \\
\hline 21 & Ethyl tetracosanoate $\mathrm{C} 24: 0$ & $\mathrm{C}_{26} \mathrm{H}_{52} \mathrm{O}_{2}$ & 396 & 39.45 & 1.29 & \\
\hline 22 & Methyl pentacosanoate $\mathrm{C} 25: 0$ & $\mathrm{C}_{26} \mathrm{H}_{52} \mathrm{O}_{2}$ & 396 & 40.06 & 0.49 & \\
\hline 59 & Unidentified & & & 40.62 & & 1.73 \\
\hline 23 & Ethyl pentacosanoate $\mathrm{C} 25: 0$ & $\mathrm{C}_{27} \mathrm{H}_{54} \mathrm{O}_{2}$ & 410 & 41.14 & 0.1 & \\
\hline 24 & Methyl hexacosanoate C26:0 & $\mathrm{C}_{27} \mathrm{H}_{54} \mathrm{O}_{2}$ & 410 & 41.78 & 3.29 & 3.08 \\
\hline 25 & Ethyl hexacosanoate C26:0 & $\mathrm{C}_{28} \mathrm{H}_{58} \mathrm{O}_{2}$ & 424 & 42.78 & 0.74 & \\
\hline 26 & Stigmastatriene & $\mathrm{C}_{29} \mathrm{H}_{46}$ & 394 & 43.13 & 0.04 & \\
\hline 27 & Methyl heptacosanoate C27:0 & $\mathrm{C}_{28} \mathrm{H}_{56} \mathrm{O}_{2}$ & 424 & 43.37 & 0.22 & \\
\hline 60 & Unidentified & & & 43.93 & & 2.82 \\
\hline 28 & Stigmastadiene & $\mathrm{C}_{29} \mathrm{H}_{48}$ & 396 & 44.10 & 0.06 & \\
\hline 29 & $\alpha$-Tocopherol (vitamin E) & $\mathrm{C}_{29} \mathrm{H}_{50} \mathrm{O}_{2}$ & 430 & 44.83 & 0.02 & \\
\hline 30 & Methyl octacosanoate C28:0 & $\mathrm{C}_{29} \mathrm{H}_{58} \mathrm{O}_{2}$ & 438 & 44.99 & 1.88 & 3.19 \\
\hline 31 & Ethyl octacosanoate C28:0 & $\mathrm{C}_{30} \mathrm{H}_{60} \mathrm{O}_{2}$ & 452 & 45.95 & 0.36 & \\
\hline 32 & Campesterol & $\mathrm{C}_{28} \mathrm{H}_{48} \mathrm{O}$ & 400 & 46.36 & 1.67 & \\
\hline 33 & Campestanol & $\mathrm{C}_{28} \mathrm{H}_{50} \mathrm{O}$ & 402 & 46.52 & 0.07 & \\
\hline 34 & Stigmasterol & $\mathrm{C}_{29} \mathrm{H}_{48} \mathrm{O}$ & 412 & 46.81 & 4.75 & \\
\hline 61 & Unidentified & & & 47.01 & & 3.47 \\
\hline
\end{tabular}


Table 1. Cont.

\begin{tabular}{|c|c|c|c|c|c|c|}
\hline & Chemical Constituents & Molecular Formula & $\operatorname{EIMS}\left[\mathbf{M}^{+*}\right]$ & Rt (min) & HEX $(\%)$ & DCM (\%) \\
\hline 35 & Sitosterol & $\mathrm{C}_{29} \mathrm{H}_{50} \mathrm{O}$ & 414 & 47.76 & 2.97 & \\
\hline 36 & $\beta$-Amyrenone & $\mathrm{C}_{30} \mathrm{H}_{48} \mathrm{O}$ & 424 & 47.81 & 0.4 & \\
\hline 37 & $\beta$-Amyrin & $\mathrm{C}_{30} \mathrm{H}_{50} \mathrm{O}$ & 426 & 48.36 & 1.05 & \\
\hline 38 & Campestenone & $\mathrm{C}_{28} \mathrm{H}_{46} \mathrm{O}$ & 398 & 48.41 & 0.87 & \\
\hline 39 & Lupenone & $\mathrm{C}_{30} \mathrm{H}_{48} \mathrm{O}$ & 424 & 48.74 & 5.35 & \\
\hline 40 & Stigmasta-4,22-dien-3-one & $\mathrm{C}_{29} \mathrm{H}_{46} \mathrm{O}$ & 410 & 48.97 & 2.47 & \\
\hline 41 & Lupeol & $\mathrm{C}_{30} \mathrm{H}_{50} \mathrm{O}$ & 426 & 49.42 & 14.7 & 3.26 \\
\hline 42 & Sitostenone & $\mathrm{C}_{29} \mathrm{H}_{48} \mathrm{O}$ & 412 & 50.01 & 2.74 & \\
\hline 43 & 3-Oxo-olean-18-en-28-oic acid methyl ester & $\mathrm{C}_{31} \mathrm{H}_{48} \mathrm{O}_{3}$ & 468 & 50.75 & 0.56 & \\
\hline 44 & 3-Oxo-olean-12-en-28-oic acid methyl ester & $\mathrm{C}_{31} \mathrm{H}_{48} \mathrm{O}_{3}$ & 468 & 51.54 & 0.26 & \\
\hline 45 & 3-Oxo-lup-20(29)-en-28-oic acid methyl ester & $\mathrm{C}_{31} \mathrm{H}_{48} \mathrm{O}_{3}$ & 468 & 51.91 & 1.20 & \\
\hline 46 & 3ß-Hydroxy-lup-20(29)-en-28-oic acid methyl ester & $\mathrm{C}_{31} \mathrm{H}_{50} \mathrm{O}_{3}$ & 470 & 52.81 & 4.25 & 70.3 \\
\hline 47 & 3-Oxo-urs-12-en-28-oic acid methyl ester & $\mathrm{C}_{31} \mathrm{H}_{48} \mathrm{O}_{3}$ & 468 & 53.05 & 0.24 & \\
\hline 48 & $3 \beta$-Acetoxy-olean-18-en-28-oic acid methyl ester & $\mathrm{C}_{33} \mathrm{H}_{52} \mathrm{O}_{4}$ & 512 & 53.49 & 2.76 & \\
\hline 49 & Stigmastane-3,6-dione & $\mathrm{C}_{29} \mathrm{H}_{48} \mathrm{O}_{2}$ & 428 & 53.62 & 0.36 & \\
\hline 50 & $3 \beta$-Acetoxy-olean-12-en-28-oic acid methyl ester & $\mathrm{C}_{33} \mathrm{H}_{52} \mathrm{O}_{4}$ & 512 & 54.43 & 0.71 & \\
\hline 51 & $3 \beta$-Acetoxy-lup-20(29)-en-28-oic acid methyl ester & $\mathrm{C}_{33} \mathrm{H}_{52} \mathrm{O}_{4}$ & 512 & 54.80 & 0.99 & \\
\hline 52 & $3 \beta$-Acetoxy-urs-12-en-28-oic acid methyl ester & $\mathrm{C}_{33} \mathrm{H}_{52} \mathrm{O}_{4}$ & 512 & 56.16 & 2.20 & 1.24 \\
\hline
\end{tabular}


Compound identification in the GC-qMS analysis was performed using retention time and interpretation of the mass spectra (molecular ion $\left[\mathrm{M}^{+*}\right]$, base peak and main fragments) in comparison with mass spectra of isolated compounds, computational libraries and literature data [29-32].

Major components identified in the hexane fraction of $M$. caesalpiniifolia were fatty acid derivatives (49.35\%), triterpenes (34.67\%) and steroids $(16.00 \%)$, and the dichloromethane fraction was dominated by triterpenes $(74.80 \%)$. The total fatty acid composition of the hexane fraction showed methyl ester $(\mathrm{m} / \mathrm{z} 74)$ and ethyl ester $(\mathrm{m} / \mathrm{z} 88)$, predominantly, with fatty acid methyl esters $(39.23 \%)$, specially methyl hexadecanoate $(6.05 \%)$, methyl tetracosanoate $(4.95 \%)$ and unsaturated fatty acid methyl ester C18:2 cis-9,cis-12 (8.05\%) and C18:1 cis-9 (5.13\%). Fatty acid ethyl esters occur naturally. There is evidence for the presence of ethyl ester C16:0 to C26:0 in the non-methylated subfraction F1 of the $n$-hexane fraction on a silica gel column (Section 3.3).

Steroid compounds identified in the hexane fraction of $M$. caesalpiniifolia showed a similar distribution pattern to that observed in M. artemisiana, including the presence of stenols and stenones [6]. The steroids identified were subdivided into four classes: non-oxygenated steroids $(0.10 \%)$, stenols $(9.46 \%)$, stenones $(6.08 \%)$ and diketosteroids $(0.36 \%)$. The major steroids $(>2.0 \%)$ were stigmasterol (4.75\%), sitosterol $(2.97 \%)$, sitostenone $(2.74 \%)$ and stigmasta-4,22-dien-3-one $(2.47 \%)$. In the literature, stigmasta-4,22-dien-3-one has shown moderate antitumoural activity [25].

Triterpene profiles in the hexane and dichloromethane fractions showed a variation of $34.67 \%$ and $74.80 \%$, respectively. The main compounds in the hexane and dichloromethane fractions were lupeol $(14.70 \%)$ and betulinic acid $(70.30 \%)$, respectively. In these fractions, 3-ketotriterpenoids and derivatives were observed. The identification of triterpenes was performed based on mass spectra

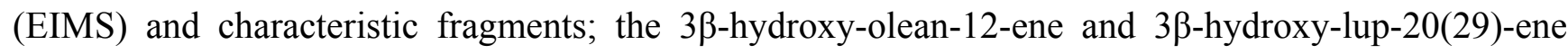
skeletons showed base peaks at $\mathrm{m} / \mathrm{z} 218$ and 189, respectively, and 3-ketotriterpenoids showed $m / z 205$ [29,30].

In addition, the presence of triterpenic acid derivatives $(13.17 \%$ to $71.54 \%)$ indicated the great metabolic biodiversity of $M$. caesalpiniifolia, mostly the high accumulation of betulinic acid (3ß-hydroxy-lup-20(29)-en-28-oic acid) in the stem bark. The triterpenic acid derivatives showed $\mathrm{m} / \mathrm{z}$ 262 for the acid methyl ester group at C-28, except in olean-18-ene acid methyl ester, which showed $\mathrm{m} / \mathrm{z}$ 248. In the urs-12-ene acid methyl ester skeleton, an additional fragment at $\mathrm{m} / \mathrm{z} 133$ (base peak) was observed [29,30].

On the other hand, $\alpha$-tocopherol was the single phenolic compound detected in the hexane fraction (relative intensity $0.02 \%$ ) using the GC-qMS extracted ion chromatogram (EIC), at $\mathrm{m} / z 165$. The fragment at $m / z 165\left[\mathrm{C}_{10} \mathrm{H}_{13} \mathrm{O}_{2}\right]^{+}$resulted from hydrogen rearrangement and retro-Diels-Alder cleavage of the pyran ring (Figures S2 and S3, Supplementary Materials). In comparative chromatograms, $\alpha$-tocopherol showed a relative abundance on the order of 100 times less than methyl octacosanoate.

The presence of phenolic compounds in the dichloromethane fraction was detected using EIC $\mathrm{m} / \mathrm{z}$ 77, 91 and 105, which correspond to related benzene ring compounds, and $m / z 94$ and 108 for phenols, including a base peak at $m / z 272\left[\mathrm{M}^{+\bullet}\right]$ indicative of $\mathrm{C}_{6}-\mathrm{C}_{3}-\mathrm{C}_{6}$ derivatives, in accordance with the NIST mass library. However, phenolic compounds in the dichloromethane fraction were found at less than $0.05 \%$ (trace level), which complicates their identification due to poor-quality spectra. 


\subsubsection{Total Phenolic and Flavonoid Contents of M. caesalpiniifolia Stem Bark}

The stem bark of $M$. caesalpiniifolia is characterised by the common occurrence of polyphenols and tannins (water-soluble phenolic compounds) [33]. The importance of polyphenols and related compounds in Mimosa species is associated with biological and pharmacological properties, such as antioxidant, cytotoxic and antimicrobial activity. Phytochemical investigation of Mimosa invisa showed the presence of phenolic substances, which include flavonoids, flavonoid glycosides and lignans with promising antiradical activity (e.g., quercetin, a well-known natural antioxidant) [5]. Two phenolic compounds (a deoxyflavone derivative and flavolignan) isolated from Mimosa diplotricha were active in an antiproliferative assay against tumour cell lines [4]. The cinnamic acid diterpenyl ester isolated from Mimosa pudica was highly active against the microorganisms Malassezia pachydermatis, Candida albicans and Staphylococcus aureus [34].

The total phenolic content (TPC) and total flavonoid content (TFC) in the ethanol extract and fractions of M. caesalpiniifolia are shown in Table 2. TPC values are expressed in milligrams of gallic acid equivalent per gram of dried plant material (mg GAE/g DPM), determined by the Folin-Ciocalteu method using gallic acid as a standard. TFC values are expressed in milligrams of rutin equivalent per gram of dried plant material (mg RE/g DPM), determined by the aluminium complex method using a rutin analytical curve.

Table 2. Total phenolic and flavonoid contents in ethanolic extract and fractions of Mimosa caesalpiniifolia stem bark.

\begin{tabular}{ccc}
\hline Samples & $\begin{array}{c}\text { TPC } \\
\text { mg GAE/g DPM }\end{array}$ & $\begin{array}{c}\text { TFC } \\
\text { mg RE/g DPM }\end{array}$ \\
\hline Ethanolic extract & $14.80 \pm 0.30$ & $1.81 \pm 0.14$ \\
Hexane fraction & $0.16 \pm 0.02$ & - \\
Dichloromethane fraction & $0.56 \pm 0.01$ & $0.35 \pm 0.01$ \\
Ethyl acetate fraction & $3.17 \pm 0.04$ & $0.34 \pm 0.02$ \\
Aqueous fraction & $6.42 \pm 0.09$ & $0.68 \pm 0.03$ \\
\hline
\end{tabular}

Notes: Mean \pm standard deviation; Total phenolic content (TPC); Total flavonoid content (TFC); milligrams of gallic acid equivalent per gram of dry plant material (mg GAE/g DPM); milligrams of rutin equivalent per gram of dry plant material (mg RE/g DPM).

The ethanolic extract had the highest total phenolic content (14.8 mg GAE/g DPM), followed by the aqueous fraction (6.42 $\mathrm{mg}$ GAE/g DPM), whereas the hexane fraction had the lowest content (0.16 mg GAE/g DPM). It was observed that the phenolic content of the extract and fractions of M. caesalpiniifolia obeyed a decreasing order: ethanol $>$ aqueous $>$ ethyl acetate $>$ dichloromethane $>$ hexane. Phenolic compounds in the hexane fraction were confirmed by GC-qMS analysis, which showed a lower accumulation of $\alpha$-tocopherol in M. caesalpiniifolia stem bark (Section 2.1.1.).

In the present investigation, the total flavonoid content (TFC) ranged from 0.34 to $1.81 \mathrm{mg}$ RE/g DPM. The ethanol extract had the highest TFC (1.81 mg RE/g DPM), followed by the aqueous extract with $0.68 \mathrm{mg} \mathrm{RE} / \mathrm{g}$ DPM. TFC extracted in solvents with different polarity were found to obey the following decreasing order: ethanol $>$ aqueous $>$ dichloromethane $\geq$ ethyl acetate $(p<0.05$, one-way ANOVA). Generally, flavonoids are rarely found in extractions and partitioning with low-polarity 
solvents such as $n$-hexane [35]. According to GC-qMS analysis, flavonoids and $\mathrm{C}_{6}-\mathrm{C}_{3}-\mathrm{C}_{6}$ derivatives were not detected in the hexane fraction. Therefore, phenolic acids, polyphenol flavonoid-like compounds and tannins in the ethanolic extract of M. caesalpiniifolia stem bark were investigated by ESI(-)-MS.

\subsubsection{Identification of Phenolic Compounds in M. caesalpiniifolia by ESI(-)-LTQ-Orbitrap-MS}

In this study, several phenolic compounds were tentatively identified in the ethanolic extract of M. caesalpiniifolia stem bark using negative electrospray ionisation coupled to a linear ion trap-orbitrap hybrid mass spectrometer (ESI(-)-LTQ-Orbitrap-MS) in the scan mode and multi-stage mass analysis $\left(\mathrm{MS}^{\mathrm{n}}\right.$ ) (Figure 3). This method provides molecular and structural information for chemical identification. The phenolic composition of ethanolic extract was analysed because this extract had the highest concentration of total phenols and flavonoids, $14.8 \mathrm{mg} \mathrm{GAE} / \mathrm{g}$ DPM and $1.81 \mathrm{mg}$ RE/g DPM (Table 2), respectively.

The ESI(-)-MS signal at $m / z 125.02[\mathrm{M}-\mathrm{H}]^{-}$suggested a trihydroxybenzene derivative, possibly pyrogallol. Hydroxybenzoic acids, with a $\mathrm{C}_{6}-\mathrm{C}_{1}$ chemical structure, showed $\mathrm{MS}^{2}$ fragments with a loss of $\mathrm{CO}_{2}[\mathrm{M}-\mathrm{H}-44]^{-}$. The $[\mathrm{M}-\mathrm{H}]^{-}$ion at $\mathrm{m} / z 169.01$ was characterised as gallic acid, and the signals at $\mathrm{m} / \mathrm{z} 183.03$ and 197.04 were identified as gallic acid derivatives: methyl gallate and ethyl gallate, respectively. Gallic acid and derivatives have been reported in Mimosa species [36]. The ion at $\mathrm{m} / \mathrm{z}$ 193.07 $[\mathrm{M}-\mathrm{H}]^{-}$was identified as ferulic acid, a $\mathrm{C}_{6}-\mathrm{C}_{3}$ structure. The deprotonated ion at $\mathrm{m} / \mathrm{z} 206.08$ was assigned to a possible nitrogen-containing compound based on the odd-mass molecular ion.

The $[\mathrm{M}-\mathrm{H}]^{-}$ion at $m / z 285.04$ with an $\mathrm{MS}^{2}$ fragment ion at $m / z 241.05\left[\mathrm{M}-\mathrm{CO}_{2}-\mathrm{H}\right]^{-}$and some typical fragments of dihydroxybenzoic acid at $m / z 153.02[\mathrm{M}-132-\mathrm{H}]^{-}$and $109.32\left[\mathrm{M}-132-\mathrm{CO}_{2}-\mathrm{H}\right]^{-}$, following the loss of a pentose sugar unit (132 Da) and decarboxylation, possibly correspond to gentisic acid aglycone (2,5-dihydroxybenzoic acid) and hydroquinone, respectively. Therefore, the ion at $m / z 285.04[\mathrm{M}-\mathrm{H}]^{-}$was identified as gentisic acid pentoside, according to previous reports that analysed the Mimosa genus [36].

The $[\mathrm{M}-\mathrm{H}]^{-}$ion at $m / z 289.07\left(\mathrm{C}_{15} \mathrm{H}_{14} \mathrm{O}_{6}\right)$ showed a $\mathrm{MS}^{2}$ fragment ion at $\mathrm{m} / z 245.08$ $\left[\mathrm{M}-\mathrm{CH}_{2} \mathrm{CHOH}-\mathrm{H}\right]^{-}$and was identified as catechin, a procyanidin monomer. Two types of procyanidin dimer were found in M. caesalpiniifolia stem bark. The low signal intensity of the $[\mathrm{M}-\mathrm{H}]^{-}$ ion at $m / z 575.11$ indicated a low accumulation level of A-type procyanidin dimers $\left(\mathrm{C}_{30} \mathrm{H}_{24} \mathrm{O}_{12}\right)$, whereas the $[\mathrm{M}-\mathrm{H}]^{-}$ion at $m / z 577.13$ showed a high level of B-type procyanidin dimers $\left(\mathrm{C}_{30} \mathrm{H}_{26} \mathrm{O}_{12}\right)$ [37]. Catechin and procyanidin dimers have previously been described in M. caesalpiniifolia leaves [24].

The $[\mathrm{M}-\mathrm{H}]^{-}$ion at 341.11 showed a $\mathrm{MS}^{2}$ ion at $\mathrm{m} / \mathrm{z} 179.05$ (caffeic acid), a loss of 162 Daltons (hexose moiety); fragment ions at $m / z 161.04\left[\mathrm{M}-162-\mathrm{H}_{2} \mathrm{O}-\mathrm{H}\right]^{-}, 143.03\left[\mathrm{M}-162-2 \mathrm{H}_{2} \mathrm{O}-\mathrm{H}\right]^{-}$and $113.02\left[\mathrm{M}-162-2 \mathrm{H}_{2} \mathrm{O}-\mathrm{H}_{2} \mathrm{CO}-\mathrm{H}\right]^{-}$, as well as a dimer ion at $m / z 683.22[2 \mathrm{M}-\mathrm{H}]^{-}$, confirmed caffeoyl hexose (Figure 3A). The signal of a deprotonated molecular ion at $m / z 377.08[\mathrm{M}-\mathrm{H}]^{-}$revealed $\mathrm{MS}^{2}$ fragment ions at $m / z 341.11\left[\mathrm{M}-2 \mathrm{H}_{2} \mathrm{O}-\mathrm{H}\right]^{-}$and $215.03[\mathrm{M}-162-\mathrm{H}]^{-}$, corresponding to the loss of a hexose unit (162 Da). The $\mathrm{MS}^{3}$ spectra for $\mathrm{m} / \mathrm{z} 341.11$ showed fragment ions at $\mathrm{m} / \mathrm{z} 179.05,161.04$, 143.03 and 113.02, which confirmed a caffeoyl hexose derivative (Figure 3B), as previously described. The signal at $m / z 377.08$ possibly corresponds to an adduct water-bridged deprotonated molecular ion $\left[\mathrm{M}+2 \mathrm{H}_{2} \mathrm{O}-\mathrm{H}\right]^{-}[38]$, which occurs due to the high concentration of caffeoyl hexose $(\mathrm{m} / \mathrm{z} 341.11$ $\left.[\mathrm{M}-\mathrm{H}]^{-}\right)$in the EtOH extract of M. caesalpiniifolia. 

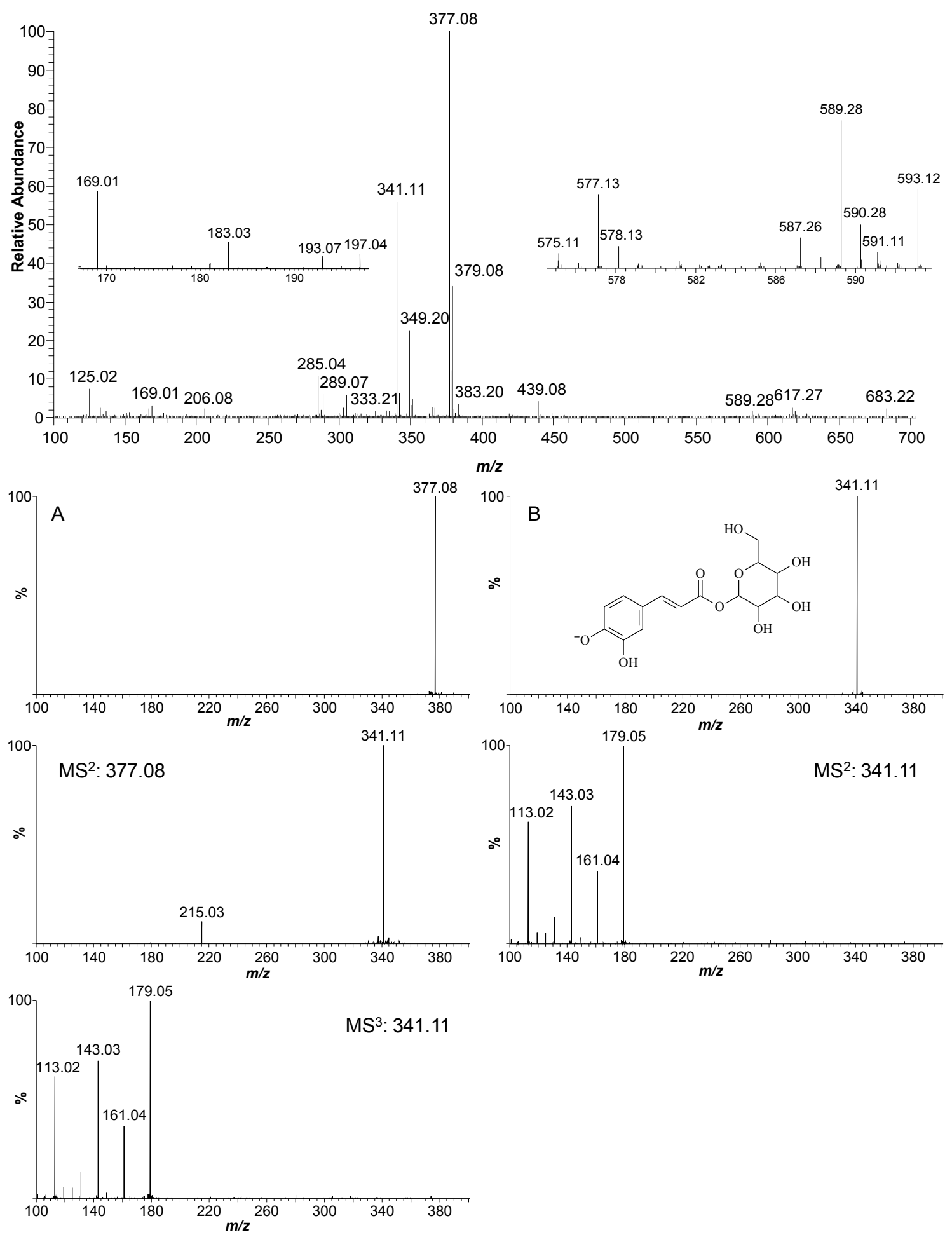

Figure 3. High-resolution fingerprint profile of ethanolic stem bark extract of Mimosa caesalpiniifolia. (A) $\mathrm{MS}^{\mathrm{n}}$ spectra of caffeoyl hexoside derivative $\left(\mathrm{m} / z 377.08[\mathrm{M}-\mathrm{H}]^{-}\right)$and (B) $\mathrm{MS}^{\mathrm{n}}$ spectra of caffeoyl hexoside $\left(\mathrm{m} / \mathrm{z} 341.11[\mathrm{M}-\mathrm{H}]^{-}\right)$.

A deprotonated ion at $\mathrm{m} / \mathrm{z} 593.12[\mathrm{M}-\mathrm{H}]^{-}$produced $\mathrm{MS}^{2}$ fragment ions at $\mathrm{m} / \mathrm{z} 575.13$ (base peak, $\left.[\mathrm{M}-18]^{-}\right), 561.12[\mathrm{M}-32]^{-}, 547.10[\mathrm{M}-46]^{-}, 473.10[\mathrm{M}-120]^{-}, 447.08,429.07,411.07$ and 285.04. According to the $\mathrm{MS}^{\mathrm{n}}$ fragmentation data, $m / z 593.12[\mathrm{M}-\mathrm{H}]^{-}$was confirmed to be vicenin-2 $\left(\mathrm{C}_{27} \mathrm{H}_{30} \mathrm{O}_{15}\right)$ [39]. Despite the presence of various $[\mathrm{M}-\mathrm{H}]^{-}$ions in the ESI(-)-MS fingerprinting of 
ethanolic extract, the plant contained a high intensity of ions at $\mathrm{m} / \mathrm{z} 377.08$ and 341.11 , which confirms a high content of caffeoyl hexose in M. caesalpiniifolia stem bark.

\subsection{Cytotoxic Activity}

The ethanolic extract, partition fractions (hexane, dichloromethane, ethyl acetate and aqueous), betulinic acid and doxorubicin (positive control) were evaluated by MTT assay against colon (HCT-116), ovarian (OVCAR-8) and glioblastoma (SF-295) tumour cell lines. The positive control doxorubicin (at $0.3 \mu \mathrm{g} / \mathrm{mL}$ ), a well-known anticancer drug that is widely used in clinical therapy [40], showed an inhibition of $>83.0 \%$ for all tumour cell lines. The percentage inhibition of cell proliferation indicates that ethanolic extract and fractions showed moderate and high cytotoxic effects, with the exception of the ethyl acetate and aqueous fractions, as shown in Figure 4.

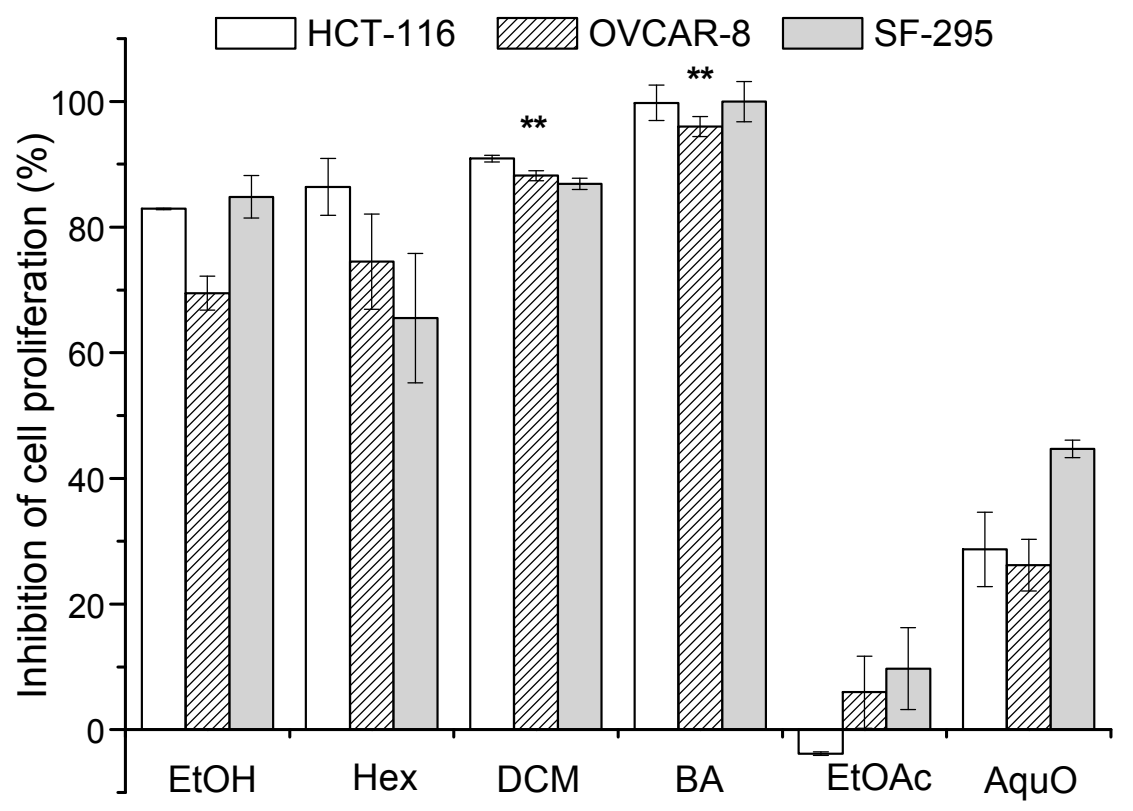

Figure 4. Percent inhibition of cell proliferation of extract and fractions of Mimosa caesalpiniifolia stem bark on cancer cell lines. HCT-116 (colon carcinoma), OVCAR-8 (ovarian carcinoma) and SF-295 (glioblastoma). EtOH (ethanolic extract), Hex (hexane fraction), DCM (dichloromethane fraction), BA (betulinic acid, isolated from hexane fraction), EtOAc (ethyl acetate fraction) and AquO (aqueous fraction). Asterisks (**) indicate no significant differences ( $p>0.05$, one-way ANOVA).

The results showed that the dichloromethane fraction and betulinic acid were the most active $(>75.0 \%)$, with inhibition of cell proliferation above $86.5 \%$, whereas the ethanolic extract and hexane fraction varied from $69.5 \%$ to $84.8 \%$ and $65.5 \%$ to $86.4 \%$, respectively. These results demonstrated that the composition of the extract and fractions contains compounds that may contribute to chemical specificity and ability to interfere on the grown tumour cells, as observed in previous cytotoxicity studies of plant extracts and fractions [41].

As mentioned above, the effectiveness of inhibition is clearly affected by the chemical composition of the extract and fractions, which may be responsible for additive, synergetic, or antagonistic effects. Our results demonstrate that the hexane fraction showed decreased activity against the glioblastoma 
tumour cell strain (SF-295) when compared with ethanolic extract, with significantly different values $(p<0.05)$. In contrast, despite the low activity of the ethyl acetate and aqueous fractions, these fractions exhibited a strong growth inhibition effect in SF-295 tumour cells, when compared with the inhibition effects in the other cell strains. In the specific case of HCT-116 tumour cells, the negative percent inhibition observed for the ethyl acetate fraction showed that there was cell growth, i.e., the fraction was inactive. The selectivity of the ethanolic extract and ethyl acetate and aqueous fractions against SF-295 tumour cells when compared with the hexane fraction is most likely due to the amount of polyphenol compounds, as shown in Table 2.

The ethanolic extract and hexane fraction showed no significant differences (one-way ANOVA, $p>0.05$ ) for the inhibition of OVCAR-8 tumour cells. The one-way ANOVA test, applied to the data describing the inhibition of cell proliferation for the dichloromethane fraction and betulinic acid, showed that differences were not significant $(p>0.05)$ for all lines tested. In this context, the dichloromethane fraction and betulinic acid showed similarly powerful responses in the inhibition of the proliferation of neoplasic cells.

The cytotoxicity results might be related with the presence of betulinic acid, which was previously isolated from the hexane fraction (subfraction F4) and identified by GC-qMS in the dichloromethane fraction with a relative abundance of $70.30 \%$. Literature, reports have shown the cytotoxic potential of betulinic acid [42,43]. Therefore, this study demonstrated that betulinic acid is the active compound responsible for the cytotoxic activity of $M$. caesalpiniifolia stem bark against tumour lines tested by the MTT assay.

It is important to highlight that the crude extract, which generally consists of a mixture of natural products such as phenolic acids, flavonoids, isoprenoids and primary metabolites such as fatty acid derivatives, was evaluated because it represents the most common approach in ethnopharmacological uses by Brazilian population. Moreover, it is likely that distinct bioactive molecules may jointly or independently contribute to the biological effects of plants $[44,45]$. Further studies are in progress to confirm these biological effects of $M$. caesalpiniifolia extracts.

\section{Experimental Section}

\subsection{General}

The solvents used in open column isolation, including $n$-hexane, dichloromethane, ethyl acetate and methanol, were analytical grade and were purchased from Synth (Labsynth, São Paulo, SP, Brazil). HPLC/spectro grade $n$-hexane, ethyl acetate and methanol were purchased from Tedia (Rio de Janeiro, RJ, Brazil). Water used was obtained from a Milli-Q system (18.2 M $\mathrm{cm}$, Milli Q-Plus system, Millipore Corporation, Bedford, MA, USA). Folin-Ciocalteu reagent was obtained from Merck (Darmstadt, Germany), aluminium chloride $\left(\mathrm{AlCl}_{3}\right)$ was obtained from Fluka Analytical (Buchs, Switzerland) and rutin was purchased from Sigma Chemical Co. (St. Louis, MO, USA). Thin-layer chromatography (TLC) plates were prepared with silica gel $60 \mathrm{G}$ (Sigma), sprayed with ceric sulphate solution and revealed on a hot plate at $100{ }^{\circ} \mathrm{C}$. Atmospheric pressure column chromatography (CC) was performed on silica gel $60(0.060-0.200 \mathrm{~mm})$ from Acros Organics (Morris Plains, NJ, USA). NMR spectra were recorded on a INOVA spectrometer (Varian, Santa Clara, CA, USA) at $400\left({ }^{1} \mathrm{H}\right)$ 
and $100 \mathrm{MHz}\left({ }^{13} \mathrm{C}\right)$, using $\mathrm{CDCl}_{3}$ as solvent. Gas chromatography-quadrupole mass spectrometry (GC-qMS) analysis was performed on a GC7890A/VLMSD5975 system (Agilent Technologies Inc., Santa Clara, CA, USA) equipped with a DB-5 capillary column (J\&W, $30 \mathrm{~m} \times 250 \mathrm{~mm} \times 0.25 \mu \mathrm{m})$ using NIST 0.8 and Wiley229 electron ionisation mass spectra (EIMS) computational libraries and authentic standards. High resolution mass spectra (HRMS) were obtained from a LTQ-Orbitrap XL (Thermo Fisher, Bremen, Germany) mass spectrometer equipped with ESI and APCI sources. Molecular absorbance measurements were determined using a Lambda 25 UV-vis spectrophotometer from PerkinElmer (Waltham, MA, USA). MTT (3-(4,5-dimethylthiazol-2-yl)-2,5-diphenyltetrazolium bromide) and doxorubicin (purity $>98 \%$ ) were purchased from Sigma Chemical Co. and RPMI-1640 medium was obtained from Cultilab (Campinas, SP, Brazil). Foetal bovine serum (FBS) and penicillin/streptomycin were purchased from Gibco-BRL (New York, NY, USA).

\subsection{Plant Material}

The stem bark of M. caesalpiniifolia was collected in Teresina, Piauí, Brazil in May 2010. The plant specimen was identified and deposited in the Graziela Barroso Herbarium with voucher specimen number TEBP 26,824.

\subsection{Extraction and Isolation of Chemical Constituents}

The stem bark was dried in air at room temperature and pulverised in a knife mill (MA680, Marconi Equipamentos Laboratório, Piracicaba, SP, Brazil). The stem bark powder (883.5 g) of M. caesalpi niifolia was extracted exhaustively with ethanol at 1:4 (w/v) plant material/solvent 10 consecutive times. The filtered and combined ethanolic extracts were concentrated under reduced pressure on a rotary evaporator (Laborota 4000, Heidolph Instruments, Schwabach, BY, Germany) and lyophilised (Edwards Micro Modulyo freeze dryer/Valpump VLP80 Savant, West Sussex, UK), yielding $36.7 \mathrm{~g}$ $(4.2 \%)$ of dried EtOH extract. The stem bark ethanol extract $(30.0 \mathrm{~g})$ was suspended in $\mathrm{MeOH}-\mathrm{H}_{2} \mathrm{O}$ $(2: 1, \mathrm{v} / \mathrm{v})$ and subjected to successive partitioning, resulting in the following fractions: $n$-hexane $(2.7 \mathrm{~g}$, 7.4\%), dichloromethane (3.9 g, 10.6\%), EtOAc (3.7 g, 10.1\%) and aqueous (13.8 g, 37.7\%). The $n$-hexane fraction $(1.0 \mathrm{~g})$ was transferred to a silica gel chromatography column and eluted with $n$-hexane-EtOAc (v/v) using a gradient of increasing polarity as the mobile phase, and subfractions were combined based on their TLC profiles. Subfraction F1 (fraction 5, $90 \mathrm{mg}, 9.0 \%$ ), eluted with $n$-hexane-EtOAc $(98: 2, \mathrm{v} / \mathrm{v})$, yielded a mixture dominated by fatty acid ethyl esters. GC-qMS analysis of the non-methylated subfraction F1 showed fatty acid ethyl esters with hydrocarbon chains C16:0 (27.54\%), C18:2 (6.04\%), C18:1 (6.28\%), C18:0 (5.31\%), C22:0 (8.70\%), C24:0 (12.07\%) and C26:0 (34.06\%). Subfraction F2 (fractions 22 to 23, $142 \mathrm{mg}, 14.2 \%$ ) yielded a mixture of 1-6 with a predominance of lupeol (4). Silica gel column chromatography of subfraction F2 using isocratic $n$-hexane-EtOAc (8:2, v/v) yielded a mixture of $\beta$-amyrin (2) and lupeol (4) (F2-1, $43 \mathrm{mg}$ ). Subfraction F3 (fractions 28 to $30,113 \mathrm{mg}, 11.3 \%$ ), eluted with $n$-hexane-EtOAc $(9: 1, \mathrm{v} / \mathrm{v})$, was recrystallised from $\mathrm{MeOH}$ to give a mixture of campesterol (7), stigmasterol (8) and sitosterol (9). Subfraction F4 (fractions 34 to $37,65 \mathrm{mg}, 6.5 \%)$, eluted with $n$-hexane-EtOAc $(8: 2, \mathrm{v} / \mathrm{v})$, was recrystallised from $\mathrm{MeOH}-\mathrm{DCM}(3: 1, \mathrm{v} / \mathrm{v})$ to yield betulinic acid (10). 


\subsection{Analysis of Non-Polar Fractions of M. caesalpiniifolia by Gas Chromatography-Quadrupole Mass Spectrometry (GC-qMS)}

The chemical constituents in the $n$-hexane and dichloromethane fractions were analysed by GC-qMS (GC7890A/VLMSD5975 system, Agilent Technologies) equipped with a DB-5 capillary column (J\&W, 5\% phenyl-95\% methylpolysiloxane, $30 \mathrm{~m} \times 250 \mathrm{~mm} \times 0.25 \mu \mathrm{m}$ ). Samples were dissolved in $n$-hexane-EtOAc $(1: 1, \mathrm{v} / \mathrm{v})$, after which previously prepared diazomethane diethyl ether solution was added. Sample aliquots of the solution $(1 \mu \mathrm{L}$ at $5 \mathrm{mg} / \mathrm{mL} \mathrm{w} / \mathrm{v})$ were injected into a gas chromatograph in split mode (10:1). Helium was used as the carrier gas at a constant flow rate of $1 \mathrm{~mL} / \mathrm{min}$. The injector temperature was set to $310^{\circ} \mathrm{C}$. GC oven temperature program: initial temperature $150{ }^{\circ} \mathrm{C}(12 \mathrm{~min})$; ramp at $4{ }^{\circ} \mathrm{C} / \mathrm{min}$ to $290{ }^{\circ} \mathrm{C}$ (23 $\left.\mathrm{min}\right)$. A mass spectrometer with quadrupole analyser was used, with electron ionisation (EI) at $70 \mathrm{eV}$, ion source at $300{ }^{\circ} \mathrm{C}$, solvent delay time 8 min and mass range scan 40-650 Da. Chemical constituents were identified through the comparison of the obtained mass spectra with Wiley229 and NIST 0.8 computational libraries and authentic standards.

\subsection{Determination and Identification of Polyphenols}

\subsubsection{Total Phenol Content}

Total phenol content (TPC) in the ethanol extract and fractions was measured using the Folin-Ciocalteu method described by Sousa et al. [46], with some modifications. Aliquots of dried samples dissolved in methanol $(0.1 \mathrm{~mL}, 1000 \mu \mathrm{g} / \mathrm{mL})$ were transferred to $10-\mathrm{mL}$ volumetric flasks, followed by the addition of Folin-Ciocalteu reagent $(0.5 \mathrm{~mL})$ and distilled water $(5 \mathrm{~mL})$, and then samples were mixed for $1 \mathrm{~min}$. Sodium carbonate $(2 \mathrm{~mL}, 15 \% \mathrm{w} / \mathrm{v})$ was added, and samples were stirred for $30 \mathrm{~s}$. The volumetric flasks were filled to $10 \mathrm{~mL}$ with distilled water and incubated at room temperature for $2 \mathrm{~h}$. The absorbance was measured at $750 \mathrm{~nm}$ using a UV-Vis spectrophotometer, and TPC content was determined in milligrams of gallic acid equivalent per gram of dry plant material (mg GAE/g DPM) using a gallic acid analytical curve $(0.1-2.5 \mu \mathrm{g} / \mathrm{mL}, \mathrm{R}=0.999)$. All analyses were performed in triplicate $(n=3)$.

\subsubsection{Total Flavonoid Content}

Total flavonoid content (TFC) in the ethanol extract and fractions was determined using the aluminium complex method and a rutin analytical curve as described by Ferreira et al. [34]. Aliquots of dried samples dissolved in methanol $(0.3 \mathrm{~mL}, 1000 \mu \mathrm{g} / \mathrm{mL})$ were transferred to $10 \mathrm{~mL}$ volumetric flasks, followed by the addition of acetic acid $(0.24 \mathrm{~mL})$, pyridine in methanol $(4 \mathrm{~mL}, 20 \% \mathrm{v} / \mathrm{v})$ and aluminium chloride methanolic solution $(1 \mathrm{~mL}, 5 \% \mathrm{w} / \mathrm{v})$. The volumetric flasks were filled to $10 \mathrm{~mL}$ with distilled water. These solutions were incubated at room temperature for $30 \mathrm{~min}$, and the absorbance was measured at $420 \mathrm{~nm}$ using a UV-Vis spectrophotometer. TFC contents were expressed in milligrams of rutin equivalent per gram of dry plant material (mg RE/g DPM) using a rutin analytical curve $(3.0-21.0 \mu \mathrm{g} / \mathrm{mL}, \mathrm{R}=0.999)$. All analyses were performed in triplicate $(n=3)$. 
3.5.3. Direct Infusion Mass Spectrometry Analysis of Ethanolic Extract of M. caesalpiniifolia Stem Bark by ESI(-)-LTQ-Orbitrap-MS

EtOH extract $(20.0 \mathrm{mg})$ of $M$. caesalpiniifolia stem bark was submitted to solid-phase extraction using a $\mathrm{C}_{18}$ Strata cartridge (500.0 mg, Phenomenez, Torrance, CA, USA). The $\mathrm{C}_{18}$ Strata cartridge was activated with methanol $(5 \mathrm{~mL})$ and subsequently water $(5 \mathrm{~mL})$. Polyphenols were eluted with $\mathrm{MeOH}-\mathrm{H}_{2} \mathrm{O}(5 \mathrm{~mL}, 8: 2, \mathrm{v} / \mathrm{v})$ in isocratic mode. The eluted fraction was evaporated under nitrogen flow, and the residue was reconstituted with $2 \mathrm{~mL}$ of $\mathrm{MeOH}-\mathrm{H}_{2} \mathrm{O}(8: 2, \mathrm{v} / \mathrm{v})$ and filtered through a Millipore membrane filter $(0.45 \mu \mathrm{m}$, PTFE) coupled to a syringe into a vial for ESI-(-)-LTQ-Orbitrap-MS analysis.

For polyphenol analysis, a LTQ Orbitrap mass spectrometer was equipped with an ESI source in negative ionisation mode. FTMS mass spectra were acquired at a resolution of 100,000 in the mass range $\mathrm{m} / \mathrm{z} 100$ to $1000 \mathrm{Da}$ on the Orbitrap analyser. The MS full mode parameters were as follows: spray voltage $3.30 \mathrm{kV}$; sheath gas 8 (arbitrary units); capillary voltage $-46 \mathrm{~V}$; capillary temperature $300{ }^{\circ} \mathrm{C}$; and tube lens $-115.14 \mathrm{~V}$. The multi-stage analysis $\left(\mathrm{MS}^{\mathrm{n}}\right)$ mode on the ion trap analyser for selected precursor ions was acquired by CID fragmentation using a normalised collision energy of 35.0. The data were processed using XCalibur software (version 2.1. Thermo Fischer Scientific Inc., San Jose, CA, USA), which provides possible elemental molecular formulas, accurate masses and isotopic patterns.

\subsection{Cytotoxicity Assay}

\subsubsection{Cell Culture}

HCT-116 (colon); OVCAR-8 (ovarian) and SF-295 (glioblastoma) tumour cell lines (National Cancer Institute, Bethesda, MD, USA) were maintained in RPMI-1640 medium supplemented with $10 \%$ foetal bovine serum (FBS) and $1 \%$ antibiotics at $37{ }^{\circ} \mathrm{C}$ with a humidified atmosphere with $5 \%$ $\mathrm{CO}_{2}$ for cell growth.

\subsubsection{Evaluation of Cell Proliferation by MTT Assay}

The cytotoxicity of ethanolic extract; the $n$-hexane, dichloromethane, ethyl acetate and aqueous fractions; and betulinic acid (isolated compound) and doxorubicin (positive control) was investigated by MTT assay [47], against HCT-116, OVCAR-8 and SF-295 cancer cells. This method analyses tumour cell growth by the ability of living cells to reduce the yellow dye 3-(4,5-dimethylthiazol-2-yl)2,5-diphenyl-tetrazolium bromide (MTT) to a blue formazan product. Briefly, cells $\left(0.1 \times 10^{6}\right.$ cells/well) were plated in 96-well plates and incubated for $72 \mathrm{~h}$ with a medium consisting of DMSO (control group); ethanol extract, fractions and subfractions at $50.0 \mu \mathrm{g} / \mathrm{mL}$; or doxorubicin $(0.3 \mu \mathrm{g} / \mathrm{mL}$, positive control). Then, the supernatant was replaced by fresh medium containing $0.15 \mathrm{~mL}$ of MTT, and the cells were incubated for an additional $3 \mathrm{~h}$. The plates were centrifuged, the formazan product was dissolved in DMSO and the absorbance was measured at $595 \mathrm{~nm}$ using a multiplate reader (DTX 880 Multimode Detector, Beckman Coulter Inc., Fullerton, CA, USA). The percentage inhibition of cell growth was calculated, according to Mahmoud et al. [41], using the software GraphPad Prism 
(GraphPad Software, Inc., La Jolla, CA, USA). The experiment was performed in triplicate, and the results were expressed as the mean \pm standard deviation (SD).

\subsection{Statistical Analysis}

A statistical approach was designed and experimental data were evaluated using one-way analysis of variance (ANOVA) using the software Origin 8.0 (OriginLab Corporation, Northampton, MA, USA), with a significance level of $p<0.05$.

\section{Supplementary Materials}

Supplementary materials can be accessed at: http://www.mdpi.com/1420-3049/20/03/4204/s1.

\section{Acknowledgments}

The authors are grateful to CNPq, CAPES and FAPEPI for the fellowships and financial support. They are also grateful to R.F.M. Barros, Graziela Barroso Herbarium (UFPI) for the identification of botanical material and F.A.M. Reis (UNICAMP) for HRMS analysis.

\section{Author Contributions}

Substantial contributions to conception and manuscript preparation: N.B.N.M., B.Q.A., A.M.G.L.C. Participated in phytochemical investigations: N.B.N.M., B.Q.A, F.P.S.A., A.M.G.L.C. Contributed to the cytotoxic experiments: J.N.S., D.J.B.L., P.M.P.F, C.P. Analysed the data: N.B.N.M., B.Q.A., A.M.G.L.C., P.M.P.F. Critical revision of the manuscript for important intellectual content: B.Q.A., A.M.G.L.C., F.P.S.A., P.M.P.F., C.P. All authors have read and approved the final manuscript.

\section{Conflicts of Interest}

The authors declare no conflict of interest.

\section{References}

1. Dutra, V.F.; Garcia, F.C.P. Three new species of Mimosa sect. Mimosa (Leguminosae, Mimosoideae) from the campos rupestres of Minas Gerais, Brazil. Brittonia 2014, 66, 33-41.

2. Gehlot, H.S.; Tak, N.; Kaushik, M.; Mitra, S.; Chen, W.M.; Poweleit, N.; Panwar, D.; Poonar, N.; Parihar, R.; Tak, A.; et al. An invasive Mimosa in India does not adopt the symbionts of its native relatives. Ann. Bot. 2013, 112, 179-196.

3. Martel-Estrada, S.A.; Olivas-Armendáriz, I.; Santos-Rodríguez, E.; Martínez-Pérez, C.A.; García-Casillas, P.E.; Hernández-Paz, J.; Rodríguez-González, C.A.; Chapa-González, C. Evaluation of in vitro bioactivity of chitosan/Mimosa tenuiflora composites. Mater. Lett. 2014, $119,146-149$.

4. Lin, L.C.; Chiou, C.T.; Cheng, J.J. 5-Deoxyflavones with cytotoxic activity from Mimosa diplotricha. J. Nat. Prod. 2011, 74, 2001-2004. 
5. Aguiar, R.M.; Alves, C.Q.; David, J.M.; Rezende, L.C.; Lima, L.S.; David, J.P.; Queiróz, L.P. Antioxidant activities of isolated compounds from stems of Mimosa invisa Mart. ex. Colla. Quim. Nova 2012, 35, 567-570.

6. Nascimento, I.A.; Braz-Filho, R.; Carvalho, M.G.; Mathias, L.; Fonseca, F.A. Flavonoides e outros compostos isolados de Mimosa artemisiana Heringer e Paula. Quim. Nova 2012, 35, 2159-2164.

7. Moraes, E.H.F.; Alvarenga, M.A.; Ferreira, Z.M.G.S. As bases nitrogenadas de Mimosa scabrella Bentham. Quim. Nova 1990, 13, 308-309.

8. Englert, J.; Weniger, B.; Lobstein, A.; Anton, R.; Krempp, E.; Guillaume, D.; Leroy, Y. Triterpenoid saponins from Mimosa pigra. J. Nat. Prod. 1995, 58, 1265-1269.

9. Nunes, X.P.; Mesquita, R.F.; Silva, D.A.; Lira, D.P.; Costa, V.C.O.; Silva, M.V.B.; Xavier, A.L.; Diniz, M.F.F.M.; Agra, M.F. Constituintes químicos, avaliação das atividades citotóxica e antioxidante de Mimosa paraibana Barneby (Mimosaceae). Rev. Bras. Farmacogn. 2008, 18, $718-723$.

10. Genest, S.; Kerr, C.; Shah, A.; Rahman, M.M.; Saif-E-Naser, G.M.M.; Nigam, P.; Nahar, L.; Sarker, S.D. Comparative bioactivity studies on two Mimosa species. Bol. Latinoam. Caribe Plant. Med. Aromat. 2008, 7, 38-43.

11. Mohan, G.; Anand, S.P.; Doss, A. Efficacy of aqueous and methanol extracts of Caesalpinia sappan L. and Mimosa pudica L. for their potential antimicrobial activity. South As. J. Biol. Sci. 2011, $1,48-57$.

12. Trevisan, M.T.S.; Macedo, F.V.V. Seleção de plantas com atividade anticolinasterase para o tratamento da doença de Alzheimer. Quim. Nova 2003, 26, 301-304.

13. Vinothapooshan, G.; Sundar, K. Anti-ulcer activity of Mimosa pudica leaves against gastric ulcer in rats. Res. J. Pharm. Biol. Chem. Sci. 2010, 1, 606-614.

14. Ahmed, T.; Imam, K.M.S.U.; Rahman, S.; Mou, S.M.; Choudhury, M.S.; Mahal, M.J.; Jahan, S.; Hossain, M.S.; Rahmatullah, M. Antihyperglycemic and antinociceptive activity of Fabaceae family plants_An evaluation of Mimosa pigra L. stems Adv. Nat. Sci. 2012, 6, 1490-1495.

15. Rakotomala, G.; Agard, C.; Tonnerre, P.; Tesse, A.; Derbré, S.; Michalet, S.; Hamzaoui, J.; Rio, M.; Cario-Toumaniantz, C.; Richomme, P.; et al. Extract from Mimosa pigra attenuates chronic experimental pulmonary hypertension. J. Ethnopharmacol. 2013, 148, 106-116.

16. Morais, C.B.; Silva, F.E.K.; Lana, A.D.; Tonello, M.L.; Luciano, S.C.; Fuentefria, A.M.; Zuanazzi, J.Â.S. Phenolic content of species from leguminosae family and their antifungal activity. Planta Med. 2012, 78, doi:10.1055/s-0032-1321016.

17. Rejón-Orantes, J.C.; Suaréz, D.P.P.; Rejón-Rodríguez, A.; Hernández, S.H.; Liévano, O.E.G.; Rodríguez, D.L.; Mora, M.P. Aqueous root extracts from Mimosa albida Humb. \& Bonpl. ex Willd display antinociceptive activity in mice. J. Ethnopharmacol. 2013, 149, 522-526.

18. Chowdhury, S.A.; Islam, J.; Rahaman, M.M.; Rahman, M.M.; Rumzhum, N.N.; Sultana, R.; Parvin, M.N. Cytotoxicity, antimicrobial and antioxidant studies of the different plant parts of Mimosa pudica. S. J. Pharm. Sci. 2008, 1, 80-84.

19. Sousa, S.M.; Reis, A.C.; Viccini, L.F. Polyploidy, B chromosomes, and heterochromatin characterization of Mimosa caesalpiniifolia Benth. (Fabaceae-Mimosoideae). Tree Genet. Genomes 2013, 9, 613-619. 
20. Ribaski, J.; Lima P.C.L.; Oliveira, V.R.; Drumond, M.A. Sabiá (Mimosa caesalpiniaefolia): Árvore de múltiplo uso no Brasil. Comunicado Técnico (Embrapa Florestas) 2003, 104, 1-4.

21. Carvalho, P.E.R. Sabiá Mimosa caesalpiniifolia. Circular Técnico da Embrapa 2007, 135, 1-7.

22. Albuquerque, U.P.; Medeiros, P.M.; Almeida, A.L.S.; Monteiro, J.M.M.; Lins Neto, E.M.F.; Melo, J.G.; Santos, J.P. Medicinal plants of the caatinga (semi-arid) vegetation of NE Brazil: A quantitative approach. J. Ethnopharmacol. 2007, 114, 325-354.

23. Monção, N.B.N.; Costa, L.M.; Arcanjo, D.D.R.; Araújo, B.Q.; Lustosa, M.C.G.; Rodrigues, K.A.F.; Carvalho, F.A.A.; Costa, A.P.R.; Citó, A.M.G. Chemical constituents and toxicological studies of leaves from Mimosa caesalpiniifolia Benth., a Brazilian honey plant. Pharmacogn. Mag. 2014, 10, S456-S462.

24. Silva, M.J.D.; Carvalho, A.J.S.; Rocha, C.Q.; Vilegas, W.; Silva, M.A.; Gouvêa, C.M.C.P. Ethanolic extract of Mimosa caesalpiniifolia leaves: Chemical characterization and cytotoxic effect on human breast cancer MCF-7 cell line. S. Afr. J. Bot. 2014, 93, 64-69.

25. Hoa, N.T.; Dien, P.H.; Quang, D.N. Cytotoxic steroids from the stem barks of Pandanus tectorius. Res. J. Phytochem. 2014, 8, 52-56.

26. Mahato, S.B.; Kundu, A. ${ }^{13}$ C-NMR spectra of pentacyclic triterpenoids-A compilation and some salient features. Phytochemistry 1994, 37, 1517-1575.

27. Wright, J.L.C.; McInnes, A.G.; Shimizu, S.; Smith, D.G.; Walter, J.A.; Idler, D.; Khalil, W. Identification of C-24 alkyl epimers of marine sterols by ${ }^{13} \mathrm{C}$ nuclear magnetic resonance spectroscopy. Can. J. Chem. 1978, 56, 1898-1093.

28. Orhan, N.; Aslan, M.; Demirci, B.; Ergun, F. A bioactivity guided study on the antidiabetic activity of Juniperus oxycedrus subsp. oxycedrus L. leaves. J. Ethnopharmacol. 2012, 140, 409-415.

29. Assimopoulou, A.N.; Papageorgiou, V.P. GC-MS analysis of penta- and tetra-cyclic triterpenes from resins of Pistacia species. Part I. Pistacia lentiscus var. Chia. Biomed. Chromatogr. 2005, 19, 285-311.

30. Modugno, F.; Ribechini, E.; Colombini, M.P. Chemical study of triterpenoid resinous materials in archaeological findings by means of direct exposure electron ionization mass spectrometry and gas chromatography/mass spectrometry. Rapid. Commun. Mass Spectrom. 2006, 20, 1787-1800.

31. Santos, D.S.; Silva, I.G.; Araújo, B.Q.; Lopes Júnior, C.A.; Monção, N.B.N.; Citó, A.M.G.L.; Souza, M.H.S.L.; Nascimento, M.D.S.B.; Costa, M.C.P. Extraction and evaluation of fatty acid composition of Orbignya phalerata Martius oils (Arecaceae) from Maranhão State, Brazil. J. Braz. Chem. Soc. 2013, 24, 355-362.

32. Zaretskii, V.I.; Vulfson, N.S.; Zaikin, V.G.; Parpenaya, I.B. Mass spectrometry of steroid systems. XII. Determination of the position of the double bond in some steroid systems by the method of fragmentation mass spectrometry. Chem. Nat. Comp. 1967, 3, 320-327.

33. Gonçalves, C.A.; Lelis, R.C.C. Teores de taninos da casca e da madeira de cinco leguminosas arbóreas. Floresta Ambient 2001, 8, 167-173.

34. Shu, W.J.; Ho, J.C. Two new antimicrobial diterpenoids from the roots of Mimosa pudica. J. Chin. Med. 2013, 24, 223-229. 
35. Ferreira, E.L.F.; Mascarenhas, T.S.; Oliveira, J.P.C.; Chaves, M.H.; Araújo, B.Q.; Cavalheiro, A.J. Phytochemical investigation and antioxidant activity of extracts of Lecythis pisonis Camb. J. Med. Plants Res. 2014, 8, 353-360.

36. Khadem, S.; Marles, R.J. Monocyclic phenolic acids; hydroxy-and polyhydroxybenzoic acids: Occurrence and recent bioactivity studies. Molecules 2010, 15, 7985-8005.

37. Li, S.; Xiao, J.; Chen, L.; Hu, C.; Chen, P.; Xie, B.; Sun, Z. Identification of A-series oligomeric procyanidins from pericarp of Litchi chinensis by FT-ICR-MS and LC-MS. Food Chem. 2012, 135, 31-38.

38. Narváez-Cuenca, C.E.; Vincken, J.P.; Gruppen, H. Identification and quantification of (dihydro) hydroxycinnamic acids and their conjugates in potato by UHPLC-DAD-ESI-MS ${ }^{n}$. Food Chem. 2012, 130, 730-738.

39. Silva, D.B.; Turatti, I.C.C.; Gouveia, D.R.; Ernst, M.; Teixeira, S.P.; Lopes, N.P. Mass spectrometry of flavonoid vicenin-2, based sunlight barriers in Lychnophora species. Sci. Rep. 2014, 4, 1-8.

40. Tacar, O.; Sriamornsak, P.; Dass, C.R. Doxorubicin: An update on anticancer molecular action, toxicity and novel drug delivery systems. J. Pharm. Pharmacol. 2013, 65, 157-170.

41. Mahmound, T.S.; Marques, M.R.; Pessoa, C.Ó.; Lotufo, L.V.C.; Magalhães, H.I.F.; Moraes, M.O.; Lima, D.P.; Tininis, A.G.; Oliveira, J.E. In vitro cytotoxic activity of Brazilian middle west plant extracts. Rev. Bras. Farmacogn. 2011, 21, 456-464.

42. Aisha, A.F.A.; Abu-Salah, K.M.; Ismail, Z.; Majid, A.M.S.A. $\alpha$-Mangostin enhances betulinic acid cytotoxicity and inhibits cisplatin cytotoxicity on HCT 116 colorectal carcinoma cells. Molecules 2012, 17, 2939-2954.

43. Zuco, V.; Supino, R.; Righetti, S.C.; Cleris, L.; Marchesi, E.; Gambacorti-Passerini, C.; Formelli, F. Selective cytotoxicity of betulinic acid on tumor cell lines, but not on normal cells. Cancer Lett. 2002, 175, 17-25.

44. Ferreira, P.M.P.; Costa-Lotufo, L.V.; Moraes, M.O.; Barros, F.W.A.; Martins, A.M.A.; Cavalheiro, A.J.; Bolzani, V.S.; Santos, A.G.; Pessoa, C. Folk uses and pharmacological properties of Casearia sylvestris: A medicinal review. An. Acad. Bras. Cienc. 2011, 83, 1373-1384.

45. Wattenberg, L.W. Chemoprevention of cancer. Cancer Res. 1985, 45, 1-8.

46. Sousa, C.M.M.; Silva, H.R.; Vieira-Júnior, G.M.; Ayres, M.C.C.; Costa, C.L.S.; Araújo, D.S.; Cavalcante, L.C.D.; Barros, E.D.S.; Araújo, P.B.M.; Brandão, M.S.; et al. Fenóis totais e atividade antioxidante de cinco plantas medicinais. Quim. Nova 2007, 30, 351-355.

47. Mosmann, T. Rapid colorimetric assay for cellular growth and survival: Application toproliferation and cytotoxicity assays. J. Immunol. Meth. 1983, 65, 55-63.

Sample Availability: Samples of the compounds 1-10 are available from the authors.

(C) 2015 by the authors; licensee MDPI, Basel, Switzerland. This article is an open access article distributed under the terms and conditions of the Creative Commons Attribution license (http://creativecommons.org/licenses/by/4.0/). 